\title{
Ascites and adnexal masses: not always ovarian or tubal carcinoma
}

\author{
Catarina Pardal, Nuno André Barros, Carla Monteiro, Paula Serrano
}

Gynecology and Obstetrics Department, Hospital de Braga, Braga, Portugal

\section{Correspondence to} Dr Catarina Pardal, catarinapardal_84@hotmail. com

Accepted 8 November 2016

\section{DESCRIPTION}

A 32-year-old Mozambican woman presented to the hospital with progressive abdominal distension, pelvic pain and low-grade fever $\left(38^{\circ} \mathrm{C}\right)$. Her family history was significant for one sister with breast cancer at the age of 40 years. In the diagnostic assessment, cancer antigen 125 (CA-125) was highly elevated $(950 \mathrm{U} / \mathrm{L})$ and the pelvic MRI showed bilateral tubal enlargement, right suspicious ovarian cyst and diffuse mesenteric thickening, A diagnosis of ovarian/tubal carcinoma with peritoneal carcinomatosis was suspected. Diagnostic laparoscopy revealed high volume ascites, bilateral tubal enlargement and peritoneal oedema, as well as multiple whitish nodules affecting uterine, adnexal and intestinal serosas and omentum thickening (video 1, figure 1), suggestive of peritoneal tuberculosis. Visual diagnosis during laparoscopy can be diagnostic in up to $95 \%$ of cases of this disease, ${ }^{1}$ but in developed countries where tuberculosis is no longer an endemic disease, these laparoscopic findings are no longer frequently seen. Histological examination of the peritoneal biopsy demonstrated the typical caseous granulomatous lesions with giant epithelioid cells of tuberculosis, although the Ziehl-Neelsen stain was negative. The diagnostic confirmation was made by the identification of Micobacterium tuberculosis DNA by the PCR method in the ascitic fluid. The patient had an uncomplicated postoperative course and was started on antituberculosis treatment. At 6 weeks of therapy, the CA-125 level was within normal range and the abdominal ultrasound scan was negative for ascitic fluid.

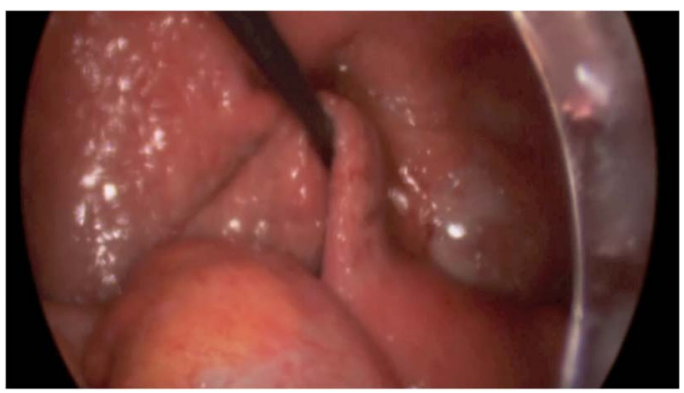

Video 1 Diagnostic laparoscopy showing bilateral tubal enlargement, ascites and multiple whitish nodules in the serosa of the uterus and adnexa, pelvic peritoneum, mesenterium, round ligament and right diaphragmatic cupola.

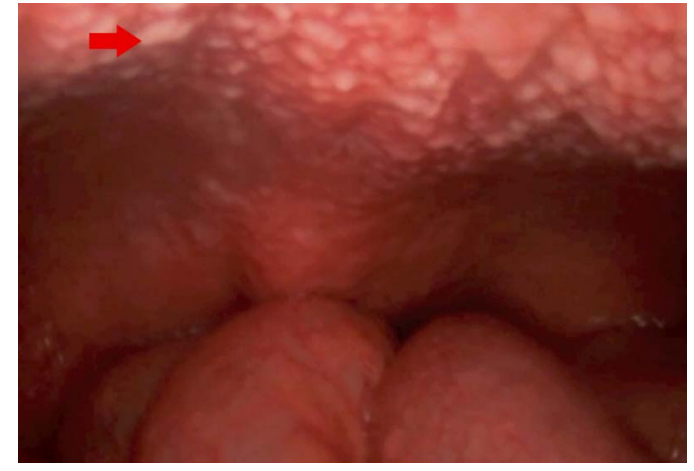

Figure 1 Anterior parietal peritoneum with the typical whitish nodules or tubercles of tuberculous peritonitis (red arrow).

\section{Learning points}

- Peritoneal tuberculosis is an insidious disease with mild symptoms and no specific signs, sometimes mimicking ovarian cancer.

- Unclear abdominal symptoms in a patient from a risk group should alert the surgeon to the possibility of abdominal tuberculosis.

- Tumour marker cancer antigen 125 is highly unspecific and could be elevated due to ascites or peritoneal inflammation.

- Laparoscopy can be diagnostic in up to $95 \%$ of cases of peritoneal tuberculosis.

- Peritoneal tuberculosis is a curable disease with good prognosis with early onset of treatment.

Contributors CP conceived the case report and drafted the manuscript. NB edited the images. CM and PS revised the manuscript critically for important intellectual content. CP, NB, CM and PS approved the final version of the manuscript to be published.

Competing interests None declared.

Patient consent Obtained.

Provenance and peer review Not commissioned; externally peer reviewed.

\section{REFERENCE}

1 Vagenas K, Stratis C, Spyropoulos C, et al. Peritoneal carcinomatosis vs peritoneal tuberculosis: a rare diagnostic dilemma in ovarian masses. Cancer Therapy 2005;3:489-94. 
Copyright 2016 BMJ Publishing Group. All rights reserved. For permission to reuse any of this content visit http://group.bmj.com/group/rights-licensing/permissions.

BMJ Case Report Fellows may re-use this article for personal use and teaching without any further permission.

Become a Fellow of BMJ Case Reports today and you can:

- Submit as many cases as you like

- Enjoy fast sympathetic peer review and rapid publication of accepted articles

- Access all the published articles

- Re-use any of the published material for personal use and teaching without further permission

For information on Institutional Fellowships contact consortiasales@bmjgroup.com

Visit casereports.bmj.com for more articles like this and to become a Fellow 